\begin{tabular}{|c|l|}
\hline Title & UNEMPLOYMENT AND INFLATION: NATURAL WAGE RATE HYPOTHESIS \\
\hline Sub Title & \\
\hline Author & 大山, 道廣(OHYAMA, Michihiro) \\
\hline Publisher & Keio Economic Society, Keio University \\
\hline Publication year & 1987 \\
\hline Jtitle & Keio economic studies Vol.24, No.2 (1987. ),p.11- 26 \\
\hline JaLC DOI & \\
\hline Abstract & $\begin{array}{l}\text { This paper presents a simple macroeconomic model designed to explain both stagnation and } \\
\text { stagflation. The money wage rate, fixed in the short run, is assumed to be adjusted over time, so } \\
\text { as to realize the natural wage rate, which is determined in each society depending on its } \\
\text { economic and social conditions. In the context of this model, stagnation is shown to arise from a } \\
\text { decline in the aggregate expenditure, and stagflation from a rise in the natural wage rate relative } \\
\text { to labor productivity under alternative hypotheses of price expectations. }\end{array}$ \\
\hline Notes & \multicolumn{1}{|l}{} \\
\hline Genre & Journal Article \\
\hline URL & $\begin{array}{l}\text { https://koara.lib.keio.ac.jp/xoonips/modules/xoonips/detail.php?koara_id=AA00260492-1987000 } \\
\text { 2-0011 }\end{array}$ \\
\hline
\end{tabular}

慶應義塾大学学術情報リポジトリ(KOARA)に掲載されているコンテンツの著作権は、それぞれの著作者、学会または出版社/発行者に帰属し、その権利は著作権法によって 保護されています。引用にあたっては、著作権法を遵守してご利用ください。

The copyrights of content available on the KeiO Associated Repository of Academic resources (KOARA) belong to the respective authors, academic societies, or publishers/issuers, and these rights are protected by the Japanese Copyright Act. When quoting the content, please follow the Japanese copyright act. 


\title{
UNEMPLOYMENT AND INFLATION: NATURAL WAGE RATE HYPOTHESIS
}

\author{
Michihiro OHYAma
}

\begin{abstract}
This paper presents a simple macroeconomic model designed to explain both stagnation and stagflation. The money wage rate, fixed in the short run, is assumed to be adjusted over time, so as to realize the natural wage rate, which is determined in each society depending on its economic and social conditions. In the context of this model, stagnation is shown to arise from a decline in the aggregate expenditure, and stagflation from a rise in the natural wage rate relative to labor productivity under alternative hypotheses of price expectations.
\end{abstract}

\section{INTRODUCTION}

We have witnessed at least two distinct types of economic depression in this century, aptly named "stagnation" and "stagnation" respectively. Stagnation refers to the situation in which the general price level (or the rate of inflation) declines together with the quantitative indices of aggregate economic activities such as output and employment. Needles to say, a most important example of stagnation is the Great Depression which began in 1929 and extended into ' 30 s. In contrast, an economy is said to suffer from stagflation when the general price level (or the rate of inflation) rises in the face of falling output and employment. This form of depression was observed most typically in industrialized countries from late '60s and through '70s when they were exposed to wage explosions, oil price hikes and other cost-raising pressures.

The Keynesian theory of unemployment was developed to explain stagnation in general and the Great Depression in particular. According to it, stagnation is caused by a deficiency in the private sector's aggregate demand (i.e., consumption and investment) for output and, therefore, the remedy for stagnation is to be found either in a compensating increase in the government expenditure or in an expansion of the money supply designed to stimulate the private sector's aggregate demand. It served as a theoretical underpinning for macroeconomic policies for many years. With the advent of stagflation, however, the general validity of this theory began to be questioned because it apparently failed to explain the phenomenon and to prescribe for effective countermeasures. The monetarists led 
by Milton Friedman, particularly harsh and effective in their indictment of the Keynesian economics, put forward an alternative theory to explain stagflation on the basis of the celebrated natural rate hypothesis. ${ }^{1}$ There is no doubt that their theory made an important contribution to the understanding of unemployment and inflation, but they swang the pendulum to the opposite exte by presuming that there is virtually no involuntary unemployment at least in the long run. ${ }^{2}$ This presumption is based on nothing but their belief in the advantages of the market mechanism.

In this paper, we attempt to rationalize an eclectic viewpoint in the context of a simple macroeconomic model, which is Keynesian in the short run but becomes classical in the long run. ${ }^{3}$ The money wage rate, fixed in the short run, is assumed to be adjusted over time to realize a certain real wage rate to be determined by the economic and social conditions of the society, which we refer to as the "natural wage rate" in analogy with the classical natural price of labor. The natural wage rate may be interpreted in some special cases to coincide with the real wage rate which supports the Friedmanian natural rate of unemployment, but it is generally compatible with the existence of involuntary unemployment. ${ }^{4}$

We organize the paper as follows. In Section 2, we describe the model and define its short-run and long-run equilibria. The concept of the natural wage rate is introduced as a key element in the definition of the long-run equilibrium. In Section 3 , we formulate a dynamic adjustment process of the money wage rate on the basis of the natural wage rate hypothesis and investigate its stability under alternative hypotheses of price expectations. The Phillips curves are shown to depict the adjustment paths of the economy when expectations are stationary or rational. Finally, Section 4 is devoted to the discussion of stagnation and stagflation within the framework of the present model. Stagnation is shown to arise from a decrease in the aggregate demand for output, and stagflation from an increase in the natural wage rate relative to labor productivity under all hypotheses of price expectations. It is then argued that Keynesian policies, monetary or fiscal, are effective in combatting stagnation but powerless if employed against stagflation and that the remedy for stagflation is to be found among the measures which affect directly the magnitude of the natural wage rate relative to labor productivity.

\footnotetext{
1 See, for instance, Friedman (1977).

2 In their view, the observed employment fluctuations merely reflect adjustments in voluntary labor supply caused primarily by changing expectations about future price levels. See, for instance, Friedman (1968) and Lucas (1973).

3 See Dornbusch and Fischer (1981) for an alternative model with similar motivations.

4 The rate of unemployment associated with the natural wage rate is more in line with the noninflationary rate of unemployment discussed by Modigliani and Papademos (1975) than with the natural rate of unemployment.
} 


\section{THE MODEL: SHORT- AND LONG-RUN EQUILIBRIA}

In.this section we develop a simple macroeconomic model capable of explaining both stagnation and stagflation. The behavior of the wage rate plays an important role in distinguishing the short- and long-run equilibria in this model. In the short run, the money wage rate is assumed to be fixed so that the resulting equilibrium of the economy is of Keynesian nature in many ways. The money wage rate is, however, adjusted over time so as to achieve a certain real wage rate (or the natural wage rate) which depends on the economic and social conditions of the society. There may exist an involuntary unemployment both in the short run and in the long run.

\section{A. The Labor Market and the Short-run Equilibrium}

For simplicity, let us assume that all potential workers are alike not only in their ability to work but also in their preferences for leisure and income. If hired, each person is supposed to work for a given, standard length of time (eight hours a day, say). If unemployed, he is supposed to survive on his past savings, unemployment insurance payments and economic assistances from his friends and relatives. It then follows that all potential workers desire to be employed if an only if the

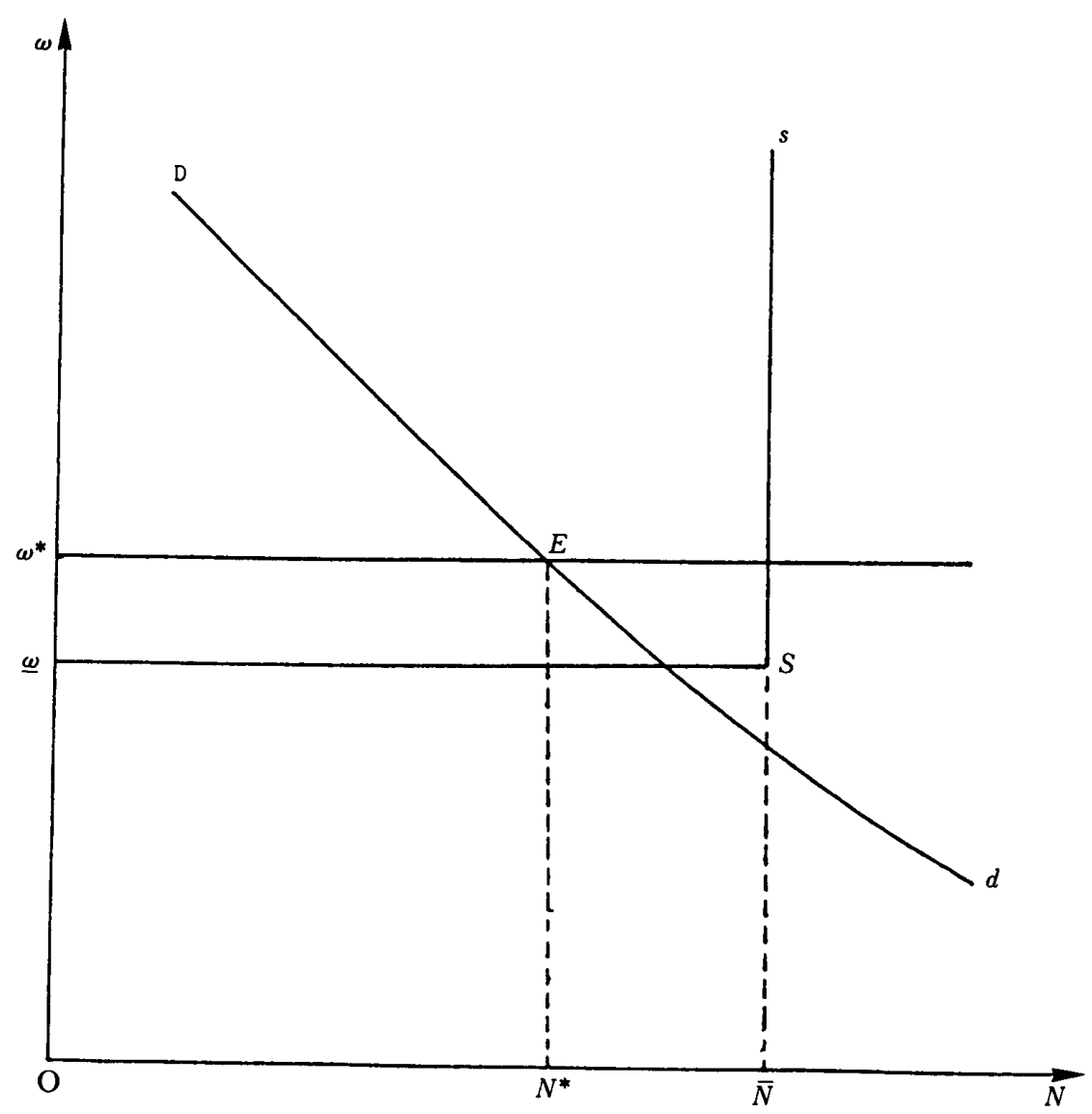

Fig. 1. 
prevailing wage rate exceeds a certain positive level, which may be called the reservation rate of labor. The aggregate supply schedule of labor may thus be illustrated by $O \omega S s$ in Fig. 1. The supply of labor is equal to the total labor force $\bar{N}$, or zero according as the existing real wage rate $\omega$ is greater or less than the reservation rate of labor $\omega$. It becomes indeterminate between $\bar{N}$ and zero if $\omega$ is just equal to $\underline{\omega}$.

The demand for labor is derived from the profit maximization of firms. The gross national product $Y$ of the economy is assumed to be a function of the aggregate employment of labor $N$ such that

$$
Y=F(N), \quad F^{\prime}(N)>0, \quad F^{\prime \prime}(N)<0 .
$$

where the stock of capital is fixed and suppressed. The profit maximization of competitive firms implies that the marginal productivity of labor be equal to the wage rate, i.e.,

$$
F^{\prime}(N)=\omega,
$$

where the real wage rate $\omega$ is defined as the ratio of the money wage rate $w$ to the price level $p$ and given by

$$
\omega=w / p .
$$

The aggregate demand schedule of labor is implicitly defined by (2). We may draw its graph as the downward sloping curve $D d$ in Fig. 1. We assume that the money wage rate is fixed in the short run. ${ }^{5}$

Let us turn to the commodity and money markets. The private sector's expenditure is assumed to be a function of the real rate of interest $r$, the real disposable income $Y-T$, and the real cash balance $R$ and written,

$$
D=D(r, Y-T, R), \quad D_{r} \leq 0, \quad D_{R}>0, \quad 0<D_{Y}<1
$$

where $T$ denotes the government tax revenue, and $D_{r}, D_{R}$ and $D_{Y}$ indicates the partial derivative of $D(\cdot)$ with respect to $r, R$ and $Y-T$, respectively. The real rate of interest $r$ is defined as the difference between the nominal rate of interest $i$ and the expected rate of inflation $\pi$, and the real cash balance $R$ as the ratio of the nominal cash balance $M$ to the price level $p$, i.e.,

$$
r=i-\pi ; \quad R=M / p
$$

The total expenditure of the economy is the sum of the private sector's expenditure $D$ and the government expediture $G$. Therefore, the equilibrium condition for the commodity market runs as

$$
Y=D(i-\pi, Y-T, M / p)+G .
$$

\footnotetext{
5 The justification of this assumption is an important task which lies outside the scope of the present study. See, for instance, Tobin (1972) and Solow (1980) for the discussion of possibilities which may account for the short-run ridigity of the money wage rate.
} 
Finally, the equilibrium condition for the money market is given by

$$
L(i, Y)=M / p, \quad L_{i}<0, \quad L_{Y}>0
$$

where $L(\cdot)$ is the standard Keynesian liquidity preference function, and $L_{i}$ and $L_{Y}$ denotes the partial derivative of $L(\cdot)$ with respect to $i$ and $Y$, respectively.

Suppose that the money wage rate $w$, the nominal cash balance $M$, government expenditure $G$, tax revenue $T$ and the expected rate of inflation $\pi$ are given exogenously in the short run. The short-run equilibrium of the economy is then defined as the state in which the marginal productivity condition (2) and the equilibrium conditions for the commodity and money markets, (4) and (5), are satisfied. The equilibrium values of the gross national product $Y$, the nominal rate of interest $i$, the employment of labor $N$ and the price level $p$ are determined by the four equations (1), (2), (4) and (5). This concept of the short-run equilibrium is analogous to the unemployment equilibrium of the standard Keynesian model. There is little need to expound it further. Clearly, it is suitable to the analysis of economic depression arising from defficient aggregate demand and rigid money wage rates. An expansionary fiscal and monetary policies are indeed capable of alleviating this kind of depression in the sense that they lead to recoveries in output and employment at least in the short run.

\section{B. The Natural Wage Rate and the Long-run Equilibrium}

The money wage rate, fixed in the short run, is assumed to be adjusted over time to attain a certain real wage rate in the long run, given the underlying structure of the economy. This long-run real wage rate is labelled the natural wage rate, a modern-day version of the natural price of labor discussed by the classical economists. ${ }^{6}$ It is determined in each society depending on a wide range of economic and social conditions such as production technologies, environmental factors, the level and composition of capital stock, the size and distribution of national wealth, labor employment practices, the bargaining power of labor unions, the level and duration of unemployment insurance payments and so on.

In some special cases, the natural wage rate may be regarded as the real wage rate which is consistent with the natural rate of unemployment defined by Friedman (1968). Generally, it does not coincide with the rate which clears the labor market. The real wage rate may be expected to converge in the long run, to such a level as to make workers clearly better off than non-workers. The reasons are as follows. First, if workers are not paid enough, they would lose the incentive to keep their job. Thus, firms may find it advantageous to set the wage rate somewhat above the resèrvation (or subsistence) rate of labor. Secondly, the labor-

\footnotetext{
${ }^{6}$ For instance, Ricardo (1817) defines it as that price of labor "which is necessary to enable the labourers, one with another, to subsist and to perpetuate their race, without either increase or dimunition," (p. 93). He also notes that "it varies at different times in the same country, and very materially differs in different countries," essentially depending on "the habits and the customs of the people." (pp. 96-97).
} 
side participants in wage bargainings often represent the interests of those who are already employed rather than the needs of those who are unemployed. At any rate, if there are non-workers who are worse-off than workers, they are involuntarily unemployed. $^{7}$

We may illustrate the determination of the natural wage rate by focusing on the special case where it is a linear function of the reservation rate of labor $\omega$, i.e., ${ }^{8}$

$$
\omega^{*}=\alpha \underline{\omega} . \quad \alpha \geq 1
$$

On the one hand, $\omega$ is affected by those factors which determine the utility level of a worker when he is unemployed. For instance, an increase in his wealth or a gain in the unemployment insurance payment raises his utility in the state of unemployment thereby increasing $\omega$. On the other hand, $\alpha$ depends on those factors which affect the wage bargaining. An increase in labor productivity, or an improvement in the bargaining power of labor unions is thus expected to raise $\alpha$. It is also conceivable that $\alpha$ is influenced by the rate of unemployment. For simplicity, however, we assume away this possibility in what follows.

In the long-run equilibrium of the economy, the real wage rate equals the natural wage rate and the expected rate of inflation coincides with the exogenously given growth rate of money supply, i.e.,

$$
\begin{aligned}
& \omega=\omega^{*}, \\
& \pi=\mu
\end{aligned}
$$

where $\mu$ denotes the growth rate of money supply. The long-run equilibrium values of labor employment and gross national product, denoted by $N^{*}$ and $Y^{*}$, respectively, are determined by equations (1), (2), and (7). Substituting these values into equations (4) and (5), and assuming a balanced budget for the government $(T=G)$, we obtain

$$
\begin{aligned}
& Y^{*}=b\left(i-\mu, Y^{*}-G, R\right)+G \\
& R=L\left(i, Y^{*}\right) .
\end{aligned}
$$

Given $\mu$ and $G$, these equations determine the equilibrium values of the real balance $R$, the nominal interest rate $i$, and the real interest rate $r(=i-\mu)$.

The position of the long-run equilibrium just defined is clearly dependent on the natural wage rate, the production function, the government expenditure and also on the growth rate of the money supply. To begin with, let us consider the effects of an increase in the natural wage rate on the long-run equilibrium of the

7 The natural wage rate seems conceptually identical to the "goal of wage policy" as defined by Pigou (1933), a great classical economist of this century. He writes that "the goal at which wage policy aims is sometimes, in some centers of production at all events, a wage rate substantially higher than the rate which, if adopted everywhere, would yield nil unemployment." (p. 253). He bases this conclusion on "several considerations" regarding the bargaining position of wage-earners and public opinion in a modern civilised state about a reasonable living wage.

8 This special case indeed arises under some simplifying assumptions. 
economy. In Fig. 1, the equilibrium value of labor employment $N^{*}$ is shown as the abscissa of the point $E$ where the $D d$ curve (depicting the marginal productivity of labor) has the height of the natural wage rate $\omega^{*}$. It should be clear that an increase in the natural wage rate brings about a reduction in labor employment, and therefore, a decrease in gross national product in the long run. Similarly, a decrease in the productivity of labor can be shown to exert depressive effects since it shifts the $D d$ curve downward.

To obtain the effects of a decrease in gross national product on the real cash balance and the rate of interest, differentiate (9) and (10) with respect $Y^{*}$. The result is:

$$
\begin{aligned}
& \frac{\partial R}{\partial Y^{*}}=-\frac{1}{\Delta}\left[D_{r} L_{Y}+\left(1-D_{Y}\right) L_{i}\right] . \\
& \frac{\partial i}{\partial Y^{*}}=\frac{1}{\Delta}\left[D_{R} L_{Y}-\left(1-D_{Y}\right)\right]
\end{aligned}
$$

where $\Delta=-\left(D_{r}+D_{R} L_{i}\right)>0$. Given the supply of money a decrease in gross national product induces a rise in the price level and leads to a reduction in the real cash balance. Its effect on the rate of interest is ambiguous.

Similarly, we can work out the effects of fiscal and monetary policies on the long-run values of these variables. An increase in the government expenditure drives the interest rate upward and reduces the real balance. Notice that it also diminishes the real disposable income of the private sector so long as it leaves intact the natural wage rate and the production function of the economy. Naturally enough, a sustained increase in the government budget cannot be justified from the private secotr's viewpoint unless it is accompanied with a compensating increase in the provision of public services.

A rise in the growth rate of money supply raises the nominal interest rate but lowers the real interest rate. It also brings about a decline in the real balance, which means a loss in the national welfare by itself. This suggests that the cost of inflation is not zero even if the future course of the price level is perfectly foreseen by the public. In this sense, money is not a veil even in the long run.

\section{THE WAGE DYNAMICS AND THE PHILLIPS CURVE}

In the preceding section, we distinguished between the "Keynesian" short-run equilibrium and the "classical" long-run equilibrium. The money wage rate is fixed in the short run, whereas the real wage rate is equalized to the natural wage rate in the long run, which is determined by the social, as well as economic conditions of the society. The task of this section is to formulate the adjustment process of the money wage rate and study its implications.

\section{A. The Adjustment of the Money Wage Rate}

We assume that the money wage rate $w$ is adjusted over time so as to (i) diminish 
the gap between the natural wage rate $\omega^{*}$ and the existing real wage rate $\omega$ on the one hand, and (ii) keep the existing real wage rate intact in view of the expected rate of inflation $\pi$ on the other hand. This process of adjustment may be described by the differential equation

$$
\frac{\dot{w}}{w}=\phi\left(\omega^{*}-\omega\right)+\pi, \quad \phi(0)=0, \quad \phi^{\prime}(0) \geqq 0
$$

where $\operatorname{dot}(\cdot)$ signifies the time derivative of the variable. This formulation is based on the presumption that in general the natural wage rate is not realized instantaneously. The money wage rate is determined by the bargaining between firms and workers, but they may not be perfectly convinced of the appropriateness of the natural wage rate before it comes into force. Thus, the realization of the natural wage rate may be resisted by workers (resp. firms) if it requires a large decrease (resp. increase) in the money wage rate.

Given the total number of potential workers $\bar{N}$, let us normalize the unit of labor such that $\bar{N}=1$. We may then rewrite (2) as

$$
\omega=F^{\prime}(1-U) \text {. }
$$

where $U$ is the rate of unemployment. In view of (11) and (12),

$$
\frac{\partial \phi}{\partial U}=\phi^{\prime} F^{\prime \prime} \leqq 0
$$

which means that the rate of change in the money wage rate defined by the dynamic equation (11) is a non-increasing function of the rate of unemployment. Therefore, equation (11) may be interpreted to represent the Phillips curve augmented by expectations (its wage-rate version). The rate of unemployment $U^{*}$ consistent with the natural wage rate $\omega^{*}$ is implicitly defined by

$$
\omega^{*}=F^{*}\left(1-U^{*}\right)
$$

As long as the natural wage rate exceeds the reservation rate of labor, $U^{*}$ stands for the share of those involuntarily unemployed in the total labor force. In general, it differs from the Friedmanian natural rate of unemployment. ${ }^{9}$

It should be noted here that the wage adjustment process defined above contains two important special cases. The one is the Keynesian case where there is no expectation of inflation $(\pi=0)$ and the money wage rate becomes downward rigid for the real wage rates higher than the natural rate $\left(\phi=0\right.$ for $\left.\omega \geqq \omega^{*}\right)$. In this case, the same rate of unemployment persists over time when $U \geqq U^{*}$. The other is the rationalist case where firms and workers are shrewd enough to realize the natural wage rate instantaneously $\left(\omega=\omega^{*}\right) .{ }^{10}$ The dynamic equation (11) then becomes $\dot{w} / w=\pi=\mu$ and, for a given value of $\pi(=\mu)$, the Phillips curve degenerates to a

$9 U^{*}$ may be said to coincide with the natural rate of unemployment only in the case where the natural wage rate happens to equal the reservation rate of labor.

${ }^{10}$ See, for instance, Sargent and Wallace (1975). 
point on the vertical line corresponding to $U^{*}$. In what follows, however, we shall consider the broad class of economies intermediate between these extreme cases.

\section{B. The Phillips Curve as the Dynamic Path of the Economy}

Suppose that the exogenous variables of long-run equilibrium such as natural wage rate, technology of production, government expenditure and growth rate of money supply are given and invariable. As the money wage rate is adjusted, the short-run equilibrium of the economy changes its position over time. The dynamic behavior of the economy is affected by the way the public forms its expectation about the rate of inflation. To compare the dynamic paths of the economy under alternative hypothesis of price expectations, we simplify the model of the preceding section by assuming that the private sector's expenditure is independent of the real rate of interest. ${ }^{11}$

(i) Stationary Expectations

First, let us consider the case where the public always expects the price level to rise at the given growth rate of money supply. In this case, we have $\pi=\mu$ so that (11) is written,

$$
\frac{\dot{w}}{w}=\phi\left(\omega^{*}-\omega\right)+\mu
$$

By the definition of $\omega(=W / p)$ and $R(=M / p)$,

$$
\frac{\dot{\omega}}{\omega}=\frac{\dot{W}}{W}-\frac{\dot{p}}{p} ; \quad \frac{\dot{R}}{R}=\mu-\frac{\dot{p}}{p} .
$$

Thus (14) is further transformed to

$$
\frac{\dot{\omega}}{\omega}=\phi(\omega-\omega)+\frac{\dot{R}}{R} .
$$

Differentiating (1)-(4) totally and assuming $D_{r}=0$ and $\mathrm{d} G=0$, we get

$$
\frac{\dot{R}}{R}=-\beta \frac{\dot{\omega}}{\omega},
$$

where

$$
\beta=-\frac{\left(1-D_{Y}\right) \omega F^{\prime}}{D_{R} R F^{\prime \prime}}>0
$$

Substituting (16) into (15) yields

$$
\frac{\dot{\omega}}{\omega}=\frac{1}{1+\beta} \phi\left(\omega^{*}-\omega\right)
$$

11 This assumption can be relaxed easily without significantly affecting our conclusions. 


$$
\frac{\mathrm{d} \dot{\omega}}{\mathrm{d} \omega}=-\frac{\omega}{1+\beta} \phi^{\prime}<0
$$

where $\omega=\omega^{*}$. This implies that the long-run equilibrium of the economy is globally stable. In view of (2), the rate of unemployment $U$ is an increasing function of $\omega$. Thus, we may conclude that if $\omega$ converges to $\omega^{*}, U$ converges to $U^{*}$.

Making use of (16), we can express the actual rate of inflation as a weighted average of the growth rate of money supply and that of money wage rate, or

$$
\frac{\dot{p}}{p}=\frac{1}{1+\beta} \mu+\frac{\beta}{1+\beta} \frac{\dot{w}}{w} \text {. }
$$

Substituting (14) into (18), we obtain

$$
\frac{\dot{p}}{p}=\frac{\beta}{1+\beta} \phi\left(\omega^{*}-\omega\right)+\mu
$$

As mentioned above, $\omega$ is an increasing function of $U$ so that (19) expresses the

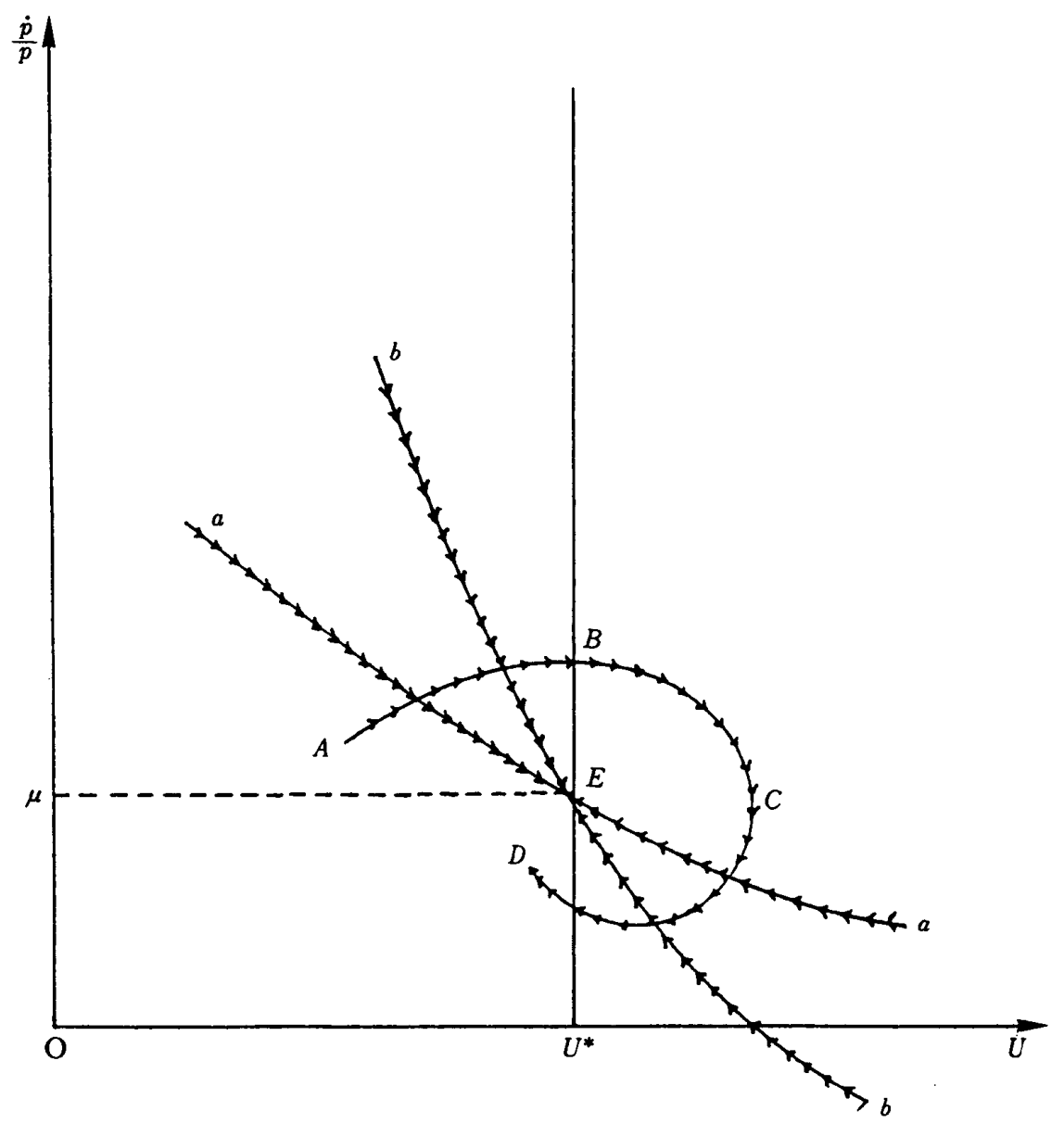

Fig. 2. 
relationship between the rate of inflation and the rate of unemployment, or the Phillips curve (its price-level version) as the dynamic path of the economy. The schedule aa in Fig. 2 illustrates this relationship. Starting from any point on this curve, the rates of inflation and unemployment rate vary along the curve in the direction indicated by arrows and converge to their long-run equilibrium values, $\mu$ and $U^{*}$, as time tends to infinity.

(ii) Rational Expectations

Next, we turn to the case where the public is perfectly informed of the structure of the economy and forms rational expectations about the rate of inflation. Set $\pi=\dot{p} / p$ in (11) to get

$$
\frac{\dot{w}}{w}=\phi\left(\omega^{*}-\omega\right)+\frac{\dot{p}}{p}
$$

or

$$
\frac{\dot{\omega}}{\omega}=\phi\left(\omega^{*}-\omega\right)
$$

From this it is clear that the long-run equilibrium is also globally stable in this case. Substituting (18) into (20) gives

$$
\frac{\dot{p}}{p}=\beta \phi(\omega-\omega)+\mu,
$$

which defines the Phillips curve relationship under the hypothesis of rational expectations. The schedule $b b$ in Fig. 2 depicts this relationship graphically. The comparison of (19) and (22) reveals that given the rate of unemployment, the speed of price adjustment is greater when the public forms its expectations rationally than when it adheres to stationary expectations. This relects the difference in the speed of wage adjustment under rational and stationary expectations. In fact, from (20) and (22), we may express the rate of money wage variation under rational expectations as

$$
\frac{\dot{w}}{w}=(1+\beta) \phi\left(\omega^{*}-\omega\right)+\mu .
$$

It should be clear that the money wage rate is adjusted more rapidly under rational expectations than under stationary expectations in response to a given difference between $\omega$ and $\omega^{*}$ (and therefore a given difference between $U$ and $U^{*}$ ).

(iii) Adaptive Expectations

Finally, let us consider briefly the case where the public modifies its price expectation sluggishly in an adaptive manner. In addition to the wage adjustment equation (11), we have to introduce a dynamic equation describing the adjustment of price expectations: 


$$
\dot{\pi}=\gamma\left(\frac{\dot{p}}{p}-\pi\right), \quad \gamma>0
$$

Making use of (19), we may rewrite (11) and (24) as

$$
\begin{aligned}
& \frac{\dot{\omega}}{\omega}=\frac{1}{1+\beta} \phi\left(\omega^{*}-\omega\right)+\pi-\mu, \\
& \dot{\pi}=\gamma\left[\frac{\beta}{1+\beta} \phi\left(\omega^{*}-\omega\right)-\pi+\mu\right] .
\end{aligned}
$$

It can be easily shown that the long-run equilibrium of the economy is locally stable and that the real wage rate and the expected rate of inflation oscillate around their equilibrium values, $\omega^{*}$ and $\mu$, in the dynamic process of adjustment.

By virtue of (18), the rate of inflation must satisfy the relationship

$$
\frac{\dot{p}}{p}=\beta \frac{\dot{\omega}}{\omega}+\mu
$$

which suggests that the rate of inflation also oscillates around its equilibrium value $\mu$. In Fig. 2, the dynamic behavior of the rates of inflation and unemployment is illustrated by the path $A B C D \cdots$, approaching the equilibrium point $E$ while oscillating around it clockwise.

\section{STAGNATION, STAGFLATION AND POLICY IMPLICATIONS}

The macro-economic model described above is designed as a simplest possible framework for the theoretical analysis of unemployment and inflation. It may be interpreted to embrace the Keynesian model of involuntary unemployment and the monetarist model of natural unemployment as its special cases. The Keynesian case may be characterized by the downward rigidity of the money wage rate which allows involuntary unemployment to persist over time, and the monetarist case by the flexibility of the money wage rate in both directions which works to wipe out involuntary unemployment at least in the long run. In this section, concerning ourselves with the more "realistic" intermediate cases, we clarify how the present model is capable of explaining both stagnation and stagflation consistently, and consider its implications for stabilization policies.

\section{A. Stagnation}

Let us define stagnation broadly as the phenomenon that the rate of unemployment rises above its conventional level, while the rate of inflation falls below its conventional level. The present model may be used to demonstrate that stagnation arises from an unanticipated decline in the aggregate expenditure of the economy under all hypotheses of price expectations. For simplicity, suppose that the economy is initially in the long-run equilibrium indicated by the intersection $E$ of 


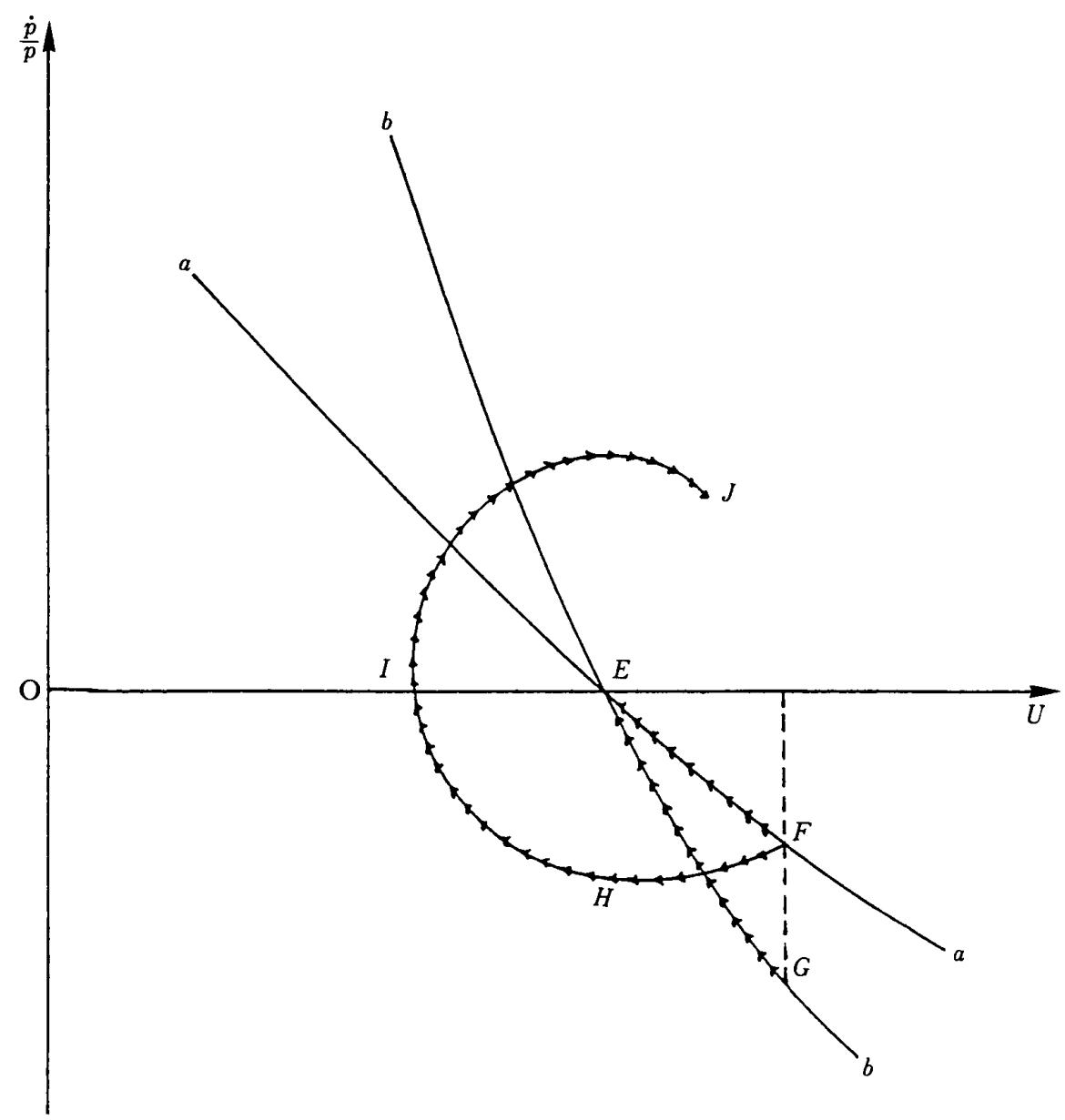

Fig. 3.

the Phillips curves, $a a$ and $b b$, with the horizontal axis in Fig. 3. (Note that the rate of inflation is initially zero.) A sudden decline in the propensity to consume, say, will shift the position of the economy from $E$ to $F$ on the Phillips curve $a a$ under stationary or adaptive expectations, and to $G$ on the Phillips curve $b b$ under rational expectations. Clearly, the impact effect of this change is to increase unemployment and lower the rate of inflation bringing down the economy into stagnation regardless of the manner the public forms their price epectations.

This is, however, not the end of the story. Since the real wage rate rises above the natural wage rate in parallel with the increase in the rate of unemployment, the money wage rate begins to be adjusted downward. As time elapses, the position of the economy moves along the Phillips curve $a a$ (resp. $b b$ ) back to the original equilibrium $E$ under stationary (rational) expectations. In the meantime, the unemployment rate falls and the inflation rate rises monotonically to their conventional levels. It should be noted here that this return to the initial position proceeds more rapidly under rational expectations than under stationary expectations. In contrast, the dynamic response of the economy is not monotonic and proceeds along an oscillatory path such as $F H I J \cdots$ to converge to $E$ under 
adaptive expectations. The economy suffers from stagnation in phase $F H$ immediately after the disturbance but evolves out of it afterward.

In any case, the economy is expected to recover automatically from the incipient stagnation. The speed of the recovery is however, another question which one cannot neglect in practice. Since the recovery from stagnation is fueled by the continuous reduction of the real wage rate realized presumably against the resistance of workers, it may take a long time for the adjustment process to terminate itself. Thus, the policy authority may be justified to speed up the recovery by employing expansionary macro-economic policies, fiscal or montary, when it is clear that the economy is in the state of stagnation.

\section{B. Stagflation}

Stagflation may be defined broadly as the phenomenon that the rates of unemployment and inflation rise above their conventional levels simultaneously. Within the framework of the present model, we can show that stagflation is the outcome of a rise in the natural wage rate relative to labor productivity under all

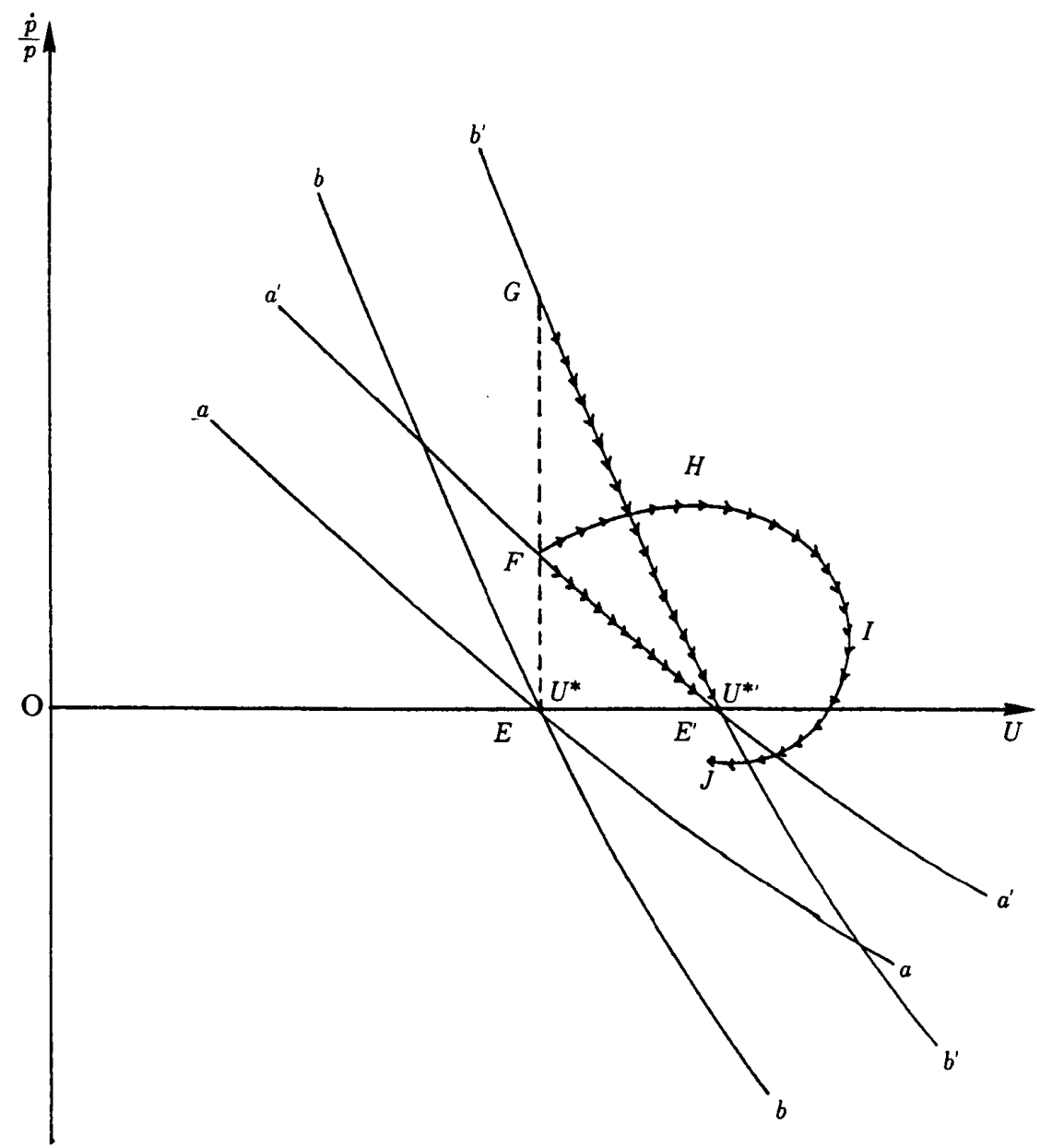

Fig. 4. 
hypotheses of price expectations. Let us suppose as before that the economy is initially in the long-run equilibrium with stable prices as indicated by point $E$ in Fig. 4. An exogenous rise in the natural wage rate (or a fall in labor productivity) increases the difference between the natural wage rate and the marginal productivity of labor at a given rate of unemployment and shifts the Phillips curves accordingly. If the supply of money remains constant, the new long-run equilibrium after this disturbance may be illustrated by the intersection $E^{\prime}$ of the new Phillips curves, $a^{\prime} a^{\prime}$ and $b^{\prime} b^{\prime}$, with the horizontal axis. As a result of this change, the long-run equilibrium rate of unemployment is shown to increase from $U^{*}$ to $U^{* \prime}$.

A rise in the natural wage rate does not affect the rate of unemployment in the short run but brings about an increase in the rate of inflation immediately. The position of the economy will jump from $E$ to $F$ under stationary and adaptive expectations, and further to $G$ under rational expectations. This is due to the upward adjustment of the money wage rate which is to take place immediately. As the real wage rate begins to rise, the rate of unemployment starts to increase as well. As time elapses, the position of the economy moves along the Phillips curve $a^{\prime} a^{\prime}$ (resp. $b^{\prime} b^{\prime}$ ) under stationary (resp. rational) expectations to converge to the new equilibrium $E^{\prime}$. The economy may be said to suffer from stagflation especially in the early stage of this process since the rate of inflation remains high and the unemployment rate rises over time. Under adaptive expectations, the adjustment process becomes oscillatory as illustrated by the path FHIJ. In this case, the emergence of stagflation is even more conspicuous since the unemployment rate and the inflation rate rise simultaneously in the beginning (i.e. in phase $G H$ ). In a similar fashion, it can be shown that a fall in labor productivity causes the economy to suffer from stagflation in the subsequent adjustment process. ${ }^{12}$

The question may now be raised as to whether and how the policy authority should intervene when the economy is in the state of stagflation. Needless to say, the answer to this question depends on one's judgement about the desirability of the current wage rate and the associated rate of unemployment under the given state of technologies. If it is judged socially desirable, the authority may be justified to promote its realization by means of contractionary macro-economic policies. As noted above, however, the natural wage rate is generally compatible with the existence of involuntary unemployment. Therefore, the long-run equilibrium under the current natural wage rate may not be socially desirable. Suppose that the economy is afflicted with stagflation and that the current rate of unemployment is already higher than the socially acceptable level. Then, what are the appropriate measures which the authority should pursus to reduce the rate of

\footnotetext{
12 Some argue that stagflation results from an unanticipated increase (caused by an increase in the money supply, say) in the aggregate expenditure. See, for instance, Dornbusch and Fischer (1981, Chap. 13). This view of stagflation differs from ours in that it allows the rate of unemployment to be below its conventional level. Note also that it is valid only if the public forms its price expectations adaptively.
} 
unemployment?

In view of the present model, it would be impractical and even harmful to try to suppress unemployment below the level associated with the natural wage rate for a long time. If the central bank adheres to an expansionary monetary policy to mantain "full employment," it is bound to accelerate the rate of inflation. An increase in the growth rate of money decreases the rate of unemployment in the short-run but does not affect it in the long-run. ${ }^{13}$ Similarly, if the government increases its expenditure for the same purpose, it has to keep raising its share in gross national product indefinitely. Obviously, these are not the outcomes acceptable to any society. This is not to deny, however, the possibility of lowering the rate of unemployment associated with the natural wage rate. First, the government may be able to help improve labor productivity by tax cuts and subsidies designed to promote work efforts as well as investments in research and development. Secondly, the natural wage rate itself is by no means unchangeable. The government may be able to affect it through incomes policies in the broad sense of the word ranging from revising the unemployment insurance system to setting guideposts for wage adjustment, to interfering in wage bargainings and so on. ${ }^{14}$

Keio University

\section{REFERENCES}

Dornbusch, R. and S. Fischer, Macroeconomics, 2nd edition, New York: McGraw Hill, 1981.

Friedman, M., "The Role of Monetary Policy," American Economic Review, March 1968, 58, 1-17. , "Nobel Lecture: Inflation and Unemployment," Journal of Political Economy, June 1977, 85, $451-472$.

Lucas, R. E. Jr., "Some International Evidence on Output-Inflation Tradeoffs, American Economic Review, June 1973, 63, 141-163.

Modigliani, F. and L. Papademos, "Targets for Monetary Policy in the Coming Year," Brookings Papers on Economic Activity, No. 1, 1975, 141-163.

Pigou, A. C., The Theory of Unemployment, London: Macmillan, 1933.

Ricardo, D., The Principles of Political Economy and Taxation, London, 1817, Sraffa Edition, London: Cambridge University Press, 1951.

Sargent, T. J. and N. Wallace, "Rational Expectations, the Optimal Monetary Instrument and the Optimal Money Supply Rule," Journal of Political Economy, April 1975, 4, 103-124.

Solow, R. M., "On Theories on Unemployment," American Economic Review, March 1980, 70, 1-11.

Tobin, J., "Inflation and Unemployment," American Economic Review, March 1972, 62, 1-18.

13 As is well known, this point is emphasized by Friedman (1968).

14 Tobin (1972) also recommends these policies though "not with great confidence or optimism." 